\title{
Resource Allocation Effect of Green Credit Policy: Based on DID Model
}

\author{
Guangyou Zhou ${ }^{1}$ (D) Chen Liu ${ }^{1}$ (D) and Sumei Luo ${ }^{2, * \mathbb{D}}$ \\ 1 School of Economics, Fudan University, Shanghai 200433, China; zgy@fudan.edu.cn (G.Z.); \\ 18210680081@fudan.edu.cn (C.L.) \\ 2 School of Finance, Shanghai University of Finance and Economics, Shanghai 200433, China \\ * Correspondence: Luosumei@shufe.edu.cn; Tel.: +86-2165908396
}

Citation: Zhou, G.; Liu, C.; Luo, S. Resource Allocation Effect of Green Credit Policy: Based on DID Model. Mathematics 2021, 9, 159. https:// doi.org/10.3390/math9020159

Received: 15 December 2020 Accepted: 11 January 2021 Published: 14 January 2021

Publisher's Note: MDPI stays neutral with regard to jurisdictional clai$\mathrm{ms}$ in published maps and institutional affiliations.

Copyright: (C) 2021 by the authors. Licensee MDPI, Basel, Switzerland. This article is an open access article distributed under the terms and conditions of the Creative Commons Attribution (CC BY) license (https:// creativecommons.org/licenses/by/ $4.0 /)$.

\begin{abstract}
From the perspective of the policy impact effect, this paper takes green enterprises as the treatment group and polluters as the control group. Firstly, the double difference method (DID) was adopted to study the effect of green credit policy on enterprises from two aspects, namely the amount of loans obtained by enterprises and the financing cost. The study found that in terms of loan volume, the launch of "Green Credit Guidelines" enabled green enterprises to obtain more credit resources than polluters. In terms of financing cost, green credit policy means green enterprises obtain lower financing cost than polluters. The triple difference method is further used to test the impact of green Credit Guidelines on the access to credit resources and financing costs of enterprises. The results show that for enterprises with different property rights, the effect of green credit policy on non-state-owned enterprises is more significant than that of state-owned enterprises. For enterprises in different regions, the policy effect of green credit policy on enterprises in regions with relatively backward economic development levels is more significant than that of enterprises in regions with relatively developed economic development level. From the empirical results, the policy basically realized the original intention of directing credit resources to green enterprises and realized the Pareto improvement of financial resource allocation.
\end{abstract}

Keywords: environmental regulation; green credit; optimal allocation; quasi-natural experiment; DID model

\section{Introduction}

Under the development of industrialization and urbanization in China, ecological environment problems have become increasingly prominent. It has become the policy objectives of the Chinese government to promote economic transformation and upgrading by supporting the development of green industries, promoting industrial transformation and upgrading, and taking the road of sustainable development. Since the vast majority of green projects are private products with certain externalities rather than pure public products, the characteristic that externalities cannot be fully internalized leads to insufficient incentives for green investment (Ma and Shi, 2014; Ma, 2015) [1,2]. The existence of externalities makes the allocation of resources deviate from Pareto optimality. When there are serious externalities, it is difficult for the market to allocate resources rationally to obtain the best performance (Altenburg and Rodrik, 2014) [3]. On the other hand, purely from the perspective of economic interests, corporate social responsibility usually conflicts with its own interests (Brammer et al., 2006; Van, 2017; Uadiale and Fagbemi, 2012) [4-6], and enterprises that do not assume social responsibility or rarely assume social responsibility generally show better financial performance than responsible enterprises (Li et al., 2017) [7]. Therefore, in addition to market constraints, the government and regulatory agencies are also required to assist in guiding the flow of resources from various policy levels, promote the development of green enterprises and promote environmental protection. In response 
to this problem, China has implemented a series of environmental regulation policies, such as green finance, green taxation and green procurement.

Green finance is essentially a financial form that can effectively allocate financial resources. The main function is to guide capital to industries with low energy consumption, low pollution and high efficiency, so as to promote the optimization of economic structure and realize a win-win situation between environment and economy (He et al., 2019) [8]. In particular, green finance in countries in transition is essentially a rationing of financial resources based on environmental constraints and a mandatory institutional reform implemented by the government (Wang et al., 2019) [9]. The main task of green finance in countries in transition is to realize the transformation from a high pollution and high energy consumption mode to a development mode of energy conservation, emission reduction, green, low carbon and high efficiency (Volz, 2018) [10]. As a way of green finance, green credit is a financial innovation to effectively control environmental pollution (Labatt and White, 2002) [11]. By studying the effect of policies, relevant scholars found that the green credit policy has the most significant effect in this series of green financial policies implemented in China (Aizawa and Yang, 2010) [12]. Since the introduction of green credit policy into China, the Chinese government has actively promoted the formulation of relevant rules on green credit policy. Banks are required to introduce an enterprise environmental risk assessment mechanism in the loan review process, guide the whole society to consume energy and resources as low as possible and strictly control credit investment to enterprises in polluting energy consumption industries, which reverses environmental deterioration to the greatest extent, makes up the ecological shortage and promotes the sustainable development of society and environment. China's policy document on green credit began with the release of the "Notice on Using Green Credit to Promote Environmental Protection" issued by the State Environmental Protection Administration in 1995 and matured with the release of the "Green Credit Guidelines" issued by the China Banking Regulatory Commission in 2012. The reason why this paper chose the "Green Credit Guidelines" issued on 24 February 2012 as the landmark event is that the document defines the standards and principles of green credit in the banking industry for the first time, and it provides detailed operational guidance on how financial institutions can effectively carry out green credit, promote green transformation of traditional industries and support the establishment of a low-carbon circular development industrial system. Since the document, China's green credit policy has entered the stage of fine management and has begun to pay more and more attention to the implementation effect of the policy.

Since the "Green Credit Guidelines" were issued, China's green credit has developed rapidly. Judging from the balance of green credit loans, the balance of loans has increased significantly. According to the data released by the China Banking Association, by the end of 2019, the green credit balance of 21 major banks in China had exceeded CNY 10 trillion, and a large amount of credit resources had flowed to green industrial enterprises (China Banking Association, 2019) [13]. From the perspective of industrial adjustment, through the adjustment of the flow of credit resources, the green credit policy has accelerated the upgrading of industrial structure and promoted the green transformation and sustainable development of the economy (He et al., 2019) [8]. The growth of the balance of green credit and the result of the adjustment of industrial structure show that the "Green Credit Guidelines" have realized the role of guiding financial resources and adjusting industrial structure, but these are the final results of the policy. In the process of exerting its effect, the policy needs to achieve its goal through the issuance of loans. There is still a lack of sufficient research on this intermediate process.

Collecting the relevant research, we find that the mainstream research focuses on its restraint mechanism and restraint effect. The original intention of the establishment of the green credit policy was to reduce the difficulty and cost of obtaining loans for green environmental protection enterprises by setting up access standards, thus realizing the inclination of credit resources to green enterprises and Pareto improvement of financial resources. 
In terms of mechanisms of action, the green credit policy has established credit criteria for enterprises and classified credit management for the degree of impact of projects on the environment. Through credit rationing, under the condition of the same capital price, the capital investment for green projects is tilted and the capital investment for other projects is relatively reduced, thus realizing resource reallocation (Wang et al., 2019) [9]. According to Stiglitz and Weiss (1981) classical theory of credit rationing, credit rationing is caused by information asymmetry. The problem of information asymmetry is highlighted as two major problems in the development of green finance: First is the adverse selection effect. The second is moral hazard. Due to adverse selection and moral hazard, polluting enterprises are theoretically willing to pay an interest rate higher than the market interest rate to obtain loans due to negative environmental externalities. As a result, polluting enterprises hope to obtain loans more than green environmental protection enterprises under the condition of market interest rate, thus causing imbalance in credit supply ( $\mathrm{Hu}, 2009)$ [14]. The green credit policy solves the externality of environmental impact caused by the production process of enterprises by tilting the capital investment in green projects. As a result, some of the loan applicants will have priority in accepting their loan applications, while others will have to pay a premium on the loan interest rate, and even if they are willing to pay a high interest rate, they may not get the loan (He et al., 2019) [8].

As for the implementation effect of green credit, previous studies mainly focus on the following five aspects. First, whether the green credit policy has curbed pollutant emissions. South Korean scholars took their own enterprises as examples to study the practical effect of green credit in South Korea. The study found that due to the implementation of green credit policy, enterprises have reduced pollution emissions (Kang et al., 2020) [15]. Polish scholars also found similar effects in their research. The study found that Poland's environmental protection bank and ecological credit policies contributed to the reduction of particulate matter emissions by $155 \mathrm{t}$, sulfur dioxide emissions by $1817 \mathrm{t}$ and nitrogen oxide emissions by $618 \mathrm{t}$ in 2013 alone (Kulpa, 2016) [16]. Second regards whether the green credit policy has changed the investment strategies of financial institutions in different industries. Taking highly polluting industries as an example, some scholars have found that the implementation of green credit policies has led financial institutions to adjust their investment strategies in pollution-intensive industries, significantly reducing the long-term debts of polluting enterprises (Wang et al., 2019) [17]. Third, whether the green credit policy has promoted or inhibited the development of enterprises. Studies have shown that the green credit policy has promoted the technological upgrading of green enterprises in the process of promoting the transformation of traditional enterprises. The main reason is that the green credit policy can increase the research and development investment of enterprises, promote technological innovation and product structure upgrading of enterprises, thus having a positive impact on technological innovation (Guo et al., 2019) [18]. For environmental protection enterprises, there is a significant positive correlation between green credit and the research and development level of enterprises, and green policies promote the development of enterprises (Chen et al., 2019) [19]. On the other hand, because the green credit policy has compressed the long-term debts of pollution-intensive enterprises, the long-term investment capacity of polluting enterprises has been compressed, which has caused significant negative effects on the development of polluting enterprises and inhibited the development of polluting enterprises (Su and Lian, 2018) [20]. Fourth, whether the green credit policy has promoted industrial upgrading and enterprise transformation. The study found that the green credit policy, guided by regulatory policies and conducted by the green financial system, guided the flow of social capital to low-carbon, environmental protection and green industries, broadened the financing channels for emerging industries, and inhibited the reinvestment expansion of pollution-intensive industrial enterprises (Guo et al., 2018) [21]. Rationalization of industrial structure and super-transformation of industrial structure are two aspects of green credit affecting industrial structure. China's green credit policy has promoted the upgrading of China's industrial structure from primary industry to secondary industry and tertiary industry, from low added value to high 
added value, and from low innovation to high innovation (Hu, 2020) [22]. In terms of studying the positive effect of green credit on enterprise transformation and supply chain optimization, Scholtens and Dam (2007) [23] took Australian companies as an example, and found that since green credit promotes enterprises to disclose information on their green operations, active disclosure of corporate social responsibility (CSR) information helps to improve enterprise performance and reduce financing costs. As far as green credit is concerned, the policy can guide money market funds from highly polluting enterprises to environmental protection enterprises (Salazar, 1998) [24], and at the same time encourage downstream manufacturers and upstream suppliers to cooperate to build a green supply chain (Kang, et al., 2020) [15], which plays an important role in the transformation and upgrading of enterprises. Fifth, the implementation of green credit by commercial banks is helpful to improve the bank's own core competitiveness, enabling banks to obtain rich profits while also improving the bank's environmental risk management capability (Cai et al., 2019) [25] and long-term operating performance (Cilliers, Diemont, Sobbelaar and Timmermans, 2010) [26]. In addition, through the improvement of environmental risks (Street and Monaghan, 2013) [27], green credit has improved the social reputation of banks (Scholtens and Dam, 2007) [23], and better liquidity has been obtained in order to reserve more liquid assets to cope with higher risks and costs (Chen et al., 2018) [28], all of which have improved the competitiveness of banks.

As most of the existing research studies on green credit policy focus on the principle and effect of the mechanism of action, the research on the key transmission step in the process of action, i.e., the credit delivery, is insufficient, and this step actually directly determines all the subsequent corporate behavior effects, which is of great importance. Therefore, this paper hopes to explore the implementation effect of green credit policy and whether the policy has realized the original intention of better allocation of credit resources by difference-in-difference (DID) from the perspective of the effect of policies on the two important indicators of loan amount and financing cost obtained by enterprises, which is more suitable for policy analysis. Therefore, based on the loan acquisition of enterprises, this paper discusses the implementation effect of "Green Credit Guidelines" by quantitatively analyzing the effect of policy implementation on target variables.

The innovation of this paper lies in: (1) introducing the two target variables of loan amount and financing cost obtained by enterprises as the criteria to measure the policy effect, and analyzing the policy effect from the two dimensions of loan amount and price. (2) In terms of index setting, the loan amount $=$ (short-term loans + long-term loans + longterm loans due in one year) the current change value/total assets of the enterprise at the beginning of the period, and the problem of loan amount difference caused by enterprise size difference is solved through "standardization". Debt cost = interest expense/interestbearing liability. Because the same company has strong substitution for debt financing through loans and bond issuance, this paper uses the debt cost to approximately replace the loan interest rate, thus solving the problem that the loan interest rate is not easy to obtain. (3) In the choice of research model, DID is adopted to analyze the impact of policy impact on green enterprises and polluting enterprises, and measure the degree of impact with the launch of "Green Credit Guidelines" in 2012 as an exogenous event, green enterprises as a treatment group and polluting enterprises as a control group. The econometric model established by DID is more suitable for policy analysis than the general regression method and can effectively alleviate the endogenous problems. (4) From the two perspectives of the nature of enterprise property rights and the region where the enterprise is located, this paper further studies the effectiveness of the introduction of "Green Credit Guidelines" on enterprises with different property rights and enterprises in different regions. The difference-in-differences-in-differences (DDD) model is used to test the mechanism, which makes the research more in-depth.

This paper carries out further research from the following aspects: the second part first analyzes the theoretical mechanism, and then puts forward research assumptions; the third part is empirical design, introducing the construction of variables, samples and 
basic models; the fourth part is empirical test and analysis; the fifth part draws research conclusions and gives policy suggestions.

\section{Theoretical Mechanisms and Research Assumptions}

The mechanism of the "Green Credit Guidelines" on companies (Figure 1) is mainly in two aspects. First, the policy requires commercial banks to implement differential credit according to the environmental and social risks of the companies applying for credit. In terms of access, the key support directions and areas of green credit are clearly defined, and special credit guidelines are formulated for restricted industries. When disbursing loans, banks are also required to analyze the environmental risks of companies and control the disbursement of loans. The supply adjustment of the financial market ultimately affects the financing decision of companies (Faulkender and Petersen, 2003; Lemmon and Roberts, 2010) [29,30]. The differentiated policy of lending to green and non-green companies finally adjusted the flow of credit resources (He et al., 2019) [31]. Second, the green credit requires commercial banks to dynamically assess and classify the environmental and social risks of companies applying for credit, and to establish different risk mitigation measures and differential pricing for different companies. Due to differential pricing, green credit policies have significantly reduced the financing costs of green companies ( $\mathrm{Xu}$ and $\mathrm{Li}, 2020)$ [32]. Therefore, we make the following assumptions:

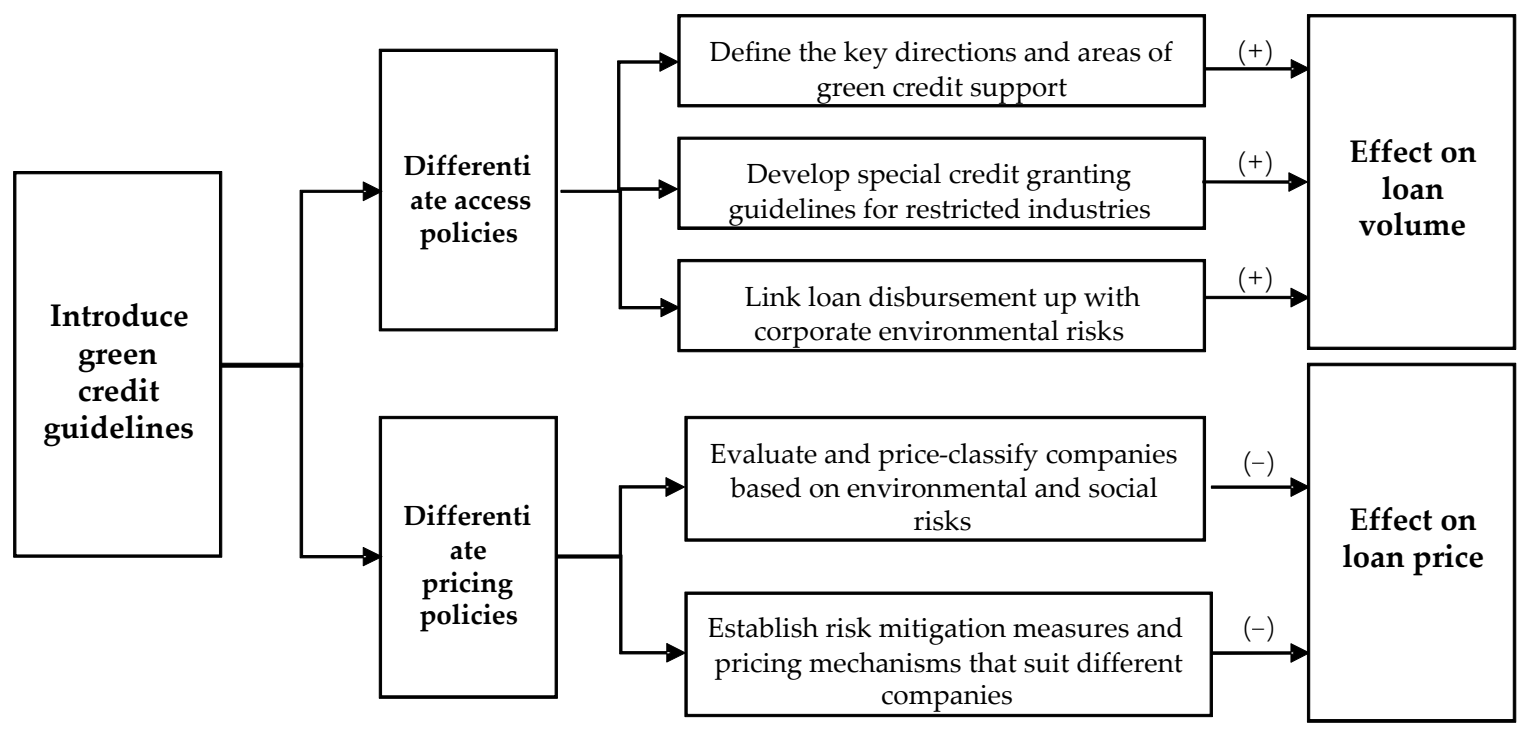

Figure 1. Impact Mechanism of Green Credit Guidelines on Company Loan Volume and Price.

Assumption 1. After the promulgation of the "Green Credit Guidelines", it will be easier for green environmental protection companies to obtain loans from polluting companies, and the amount of loans will show a relative increase.

Assumption 2. After the promulgation of the "Green Credit Guidelines", the financing costs of green environmental protection companies are lower than those of polluting companies, and the debt interest rate is lower.

For a long time, compared with state-owned companies, China's private companies usually have difficulty in raising funds from commercial banks with state-owned backgrounds, or have to pay higher costs in order to obtain bank loans. This phenomenon, known as private credit discrimination (Brandt and Li, 2003) [33], has always existed in China. From the perspective of differences in the nature of company property rights, some scholars have found that green credit policies have different effects on green companies with different property rights, while green credit policies have stronger effects on nonstate-owned companies (Su and Lian, 2018) [20]. In addition to the above differences in 
the nature of property rights, some scholars have also found that the effect of green credit policies on reducing the financing costs of green companies is also related to the level of regional economic development, and the effect of policies on companies in economically underdeveloped regions is more significant than that in economically developed regions ( $\mathrm{Xu}$ and $\mathrm{Li}, 2020$ ) [32]. Therefore, we further make the following assumptions:

Assumption 3. After the promulgation of the "Green Credit Guidelines", for companies with different property rights, the policy effect of green credit on non-state-owned companies is more significant than that of state-owned companies.

Assumption 4. After the promulgation of the "Green Credit Guidelines", for companies in different regions, the policy effect of green credit on companies in regions with relatively backward economic development level is more significant than that of companies in regions with relatively developed economic development level.

\section{Research Design}

\subsection{Data}

In the sample selection, this paper selects all A-share listed companies of Shanghai Stock Exchange and Shenzhen Stock Exchange from 1 January 2009 to 31 December 2019 as samples. The data of each variable corresponding to the company comes from Wind database and annual report of the company.

The selection of green companies comes from the list of A-share listed environmental protection companies disclosed in the "Environmental Protection Industry Prosperity Report" over the years, including companies whose main businesses are environmental protection engineering and services, water conservancy and hydropower, new energy power generation, wind power generation, photovoltaic manufacturing, garden engineering and other companies that meet the characteristics of green companies. The selection of polluting companies comes from the list of national key monitoring companies disclosed on the website of the State Ministry of Ecological Environment over the years, including companies whose main businesses are mining, oil exploitation, thermal power, chemical industry, textile, metal smelting, paper making, pharmacy, etc. At the same time, according to the main business and business scope disclosed in the annual reports and websites of listed companies over the years, manually find out whether there are clearly "environmental protection", "green" and "energy saving" contents, and more accurately judge whether there is a change from polluting companies to green companies. Ordinary companies take all A-share listed companies after excluding green companies and polluting companies as samples.

In the process of data collation, the following data are eliminated: incomplete data and specially processed company samples are eliminated; excluding listed companies in the insurance and financial industries; excluding ST listed companies; excluding the samples of listed companies without loans; eliminate some samples with serious missing data. After screening the above rules, the finally selected samples are taken as model analysis samples.

\subsection{Variable Selection}

The explanatory variables in this paper are credit and financing cost debt_cost_w of listed companies. Considering the availability of data, the financing cost is measured by "interest expense divided by the average of spot and previous interest-bearing debts". The grouping dummy variable is treated, the green company assigns a value of 1 to the treatment group and the polluting company assigns a value of 0 . The time variable is period, with 2012 as the time node for policy implementation and with 0 assigned before 2012 and 1 assigned after 2012. Size of total assets, asset-liability ratio lev, return on net assets roe, book-to-market ratio bm, return of annual stock price, volatility of annual stock price, holding of the top ten shareholders, "abs_rectified_jones" is a control variable that indicates the quality of accounting information obtained by the modified Jones model. The definitions of each variable are shown in Table 1. 
Table 1. Variable Definitions.

\begin{tabular}{cl}
\hline Variable & \multicolumn{1}{c}{ Variable Definition } \\
\hline credit & $\begin{array}{l}\text { Company Loan Amount }=\text { (Short-term Loan + Long-term Loan + Long-term Loan with one-year maturity) } \\
\text { Current Period Change Value/Company Opening Total Assets }\end{array}$ \\
\hline debt_cost_w & Debt financing cost $=2 \times$ interest expense / (interest-bearing debt $\mathrm{t}+$ interest-bearing debt $\mathrm{t}-1)$ \\
\hline treated & Green companies as the treatment group take 1, polluting companies as the control group take 0 \\
\hline period & $\begin{array}{c}\text { Taking the promulgation of the “Green Credit Guidelines" in } 2012 \text { as the policy time node, the value is 0 } \\
\text { before the implementation of the policy and } 1 \text { after the implementation. }\end{array}$ \\
\hline size & Logarithm of total assets of the company \\
\hline lev & Asset-liability ratio of companies \\
\hline roe & The rate of return on net assets of an company reflects the financial book income of the company. \\
\hline bm & Book to Market Ratio = Shareholders' Equity/Company Market Value = Countdown of Price-to-Book Ratio \\
\hline return & The annual stock price return rate reflects the investment return after absorbing all market information. \\
\hline holding & Concentration of the Top Ten Shareholders \\
\hline volatility & Annual stock price volatility \\
\hline abs_rectified_jones & $\begin{array}{l}\text { The degree of information asymmetry is measured by using the modified Jones model. The greater the } \\
\text { controllable accrual profit of the enterprise, the worse the information quality. }\end{array}$ \\
\hline
\end{tabular}

\subsection{Measurement Model}

DID is widely used in the analysis of government policy effects (Athey and Imbens, 2006) [34], which is simple and intuitive in form and helps to correct endogenous problems caused by selection bias (Meyer, 1995) [35]. The essence of this method is to divide the samples into the control group before the policy change, the control group after the policy change, the treatment group before the policy change and the treatment group after the policy change. By filtering the time effect and the internal deviation between the control group and the treatment group, the relative influence of the policy implementation on the treatment group can be accurately analyzed.

For companies, the introduction of the green credit of "Green Credit Guidelines" can be regarded as an exogenous event, so this experiment can be regarded as a quasinatural experiment. In order to test the impact of policies on company financing and the subsequent strategic response of companies, we refer to Qian Xuesong (2017) [36] and construct a treatment group and a control group based on the differences of policy effects at the company level for testing. Under the condition of a quasi-natural experiment, the DID is used to analyze the difference of the influence of the exogenous event of "Green Credit Guidelines" on the companies in the treatment group and the companies in the control group, which can overcome the influence of other factors or missing variables that interfere with the causal relationship and thus identify the causal relationship. We divide listed companies into two categories: one is green companies and the other is polluting companies. Green companies are taken as the treatment group and polluting companies are taken as the control group, thus constructing a DID model. The promulgation of the green credit will have an effect on the loan financing amount and financing cost of companies. In order to test the effect of independent variables on these two dependent variables, we set models for these two variables, respectively. In order to eliminate the difference between time and individuals, this paper uses an econometric model to control the two-way fixed effect for regression analysis. The relevant models are set as follows. Model (1) tests the effect of green credit on company credit volume:

$$
\text { Credit }_{i t}=\alpha_{0}+\alpha_{1} \text { treated }_{\mathrm{i}} \times \text { period }_{\mathrm{t}}+\gamma \mathrm{X}_{\mathrm{it}}+\mu_{\mathrm{i}}+\lambda_{\mathrm{t}}+\delta_{\mathrm{it}}
$$


Model (2) Examines the Impact of Green credit on Company Financing Cost:

$$
\text { Debt_cost_wit }=\beta_{0}+\beta_{1} \text { treated }_{i} \times \text { period }_{t}+\gamma X_{i t}+\mu_{i}+\lambda_{t}+\delta_{i t}
$$

In the model, the explained variable Credit ${ }_{i t}$ is the loan amount index of the company $i$ at time $t$, and the Debt_cos $t \_w_{i t}$ is corresponding financing cost. treated $d_{i}$ is a dummy variable, with 1 for companies in the green treatment group and 0 for companies in the pollution control group. treated $\mathrm{d}_{\mathrm{i}}$ is an indicator variable. When the sample observation value occurs after the introduction of the "Green Credit Guidelines" (i.e., 2012 and later), the value is 1 , otherwise the value is 0 ; $X_{i t}$ is the control variables, including company size, financial leverage, return on net assets, book-to-market ratio, annual stock price return, annual stock price volatility, shareholding concentration of the top ten shareholders and degree of information asymmetry; $\mu_{\mathrm{i}}$ is an individual fixed effect and $\lambda_{t}$ is a time fixed effect. We mainly pay attention to the coefficients $\alpha_{1}$ and $\beta_{1}$ of the two models treated $d_{i} \times$ period $_{t}$ ' which measure the effect of the "Green Credit Guidelines" on corporate credit acquisition and debt financing costs.

\subsection{Descriptive Statistics}

Through screening the credit data of China's A-share listed enterprises from 1 January 2009 to 31 December 2019, a total of 15,886 loan data were included in the study. Table 2 shows descriptive statistics of the main variables in the sample period, and the data of each variable are all data of the same period. Among them, the average values of the explained variables loan amount and financing cost are 0.0334 and 0.0782 , respectively, and the standard deviations are $5.48 \%$ and $7.09 \%$, respectively. The floating ranges of the two explained variables are relatively large, thus providing good materials for examining how the promulgation of the "Green Credit Guidelines" affects loan amount and financing cost. Treated_period is the cross item of group and policy implementation, which is the core explanatory variable of this study. A total of 3671 cross item data were included in the model. State-owned is the logo of state-owned enterprises. Among 15,266 enterprise samples, state-owned enterprises account for $64.4 \%$. This variable will be used in the heterogeneity test based on the nature of enterprise property rights.

Table 2. Descriptive Statistics of Main Variables.

\begin{tabular}{cccccc}
\hline & $\mathbf{( 1 )}$ & $\mathbf{( 2 )}$ & $\mathbf{( 3 )}$ & $\mathbf{( 4 )}$ & $\mathbf{( 5 )}$ \\
\hline Variables & $\boldsymbol{n}$ & Mean & $\mathbf{s d}$ & Min & Max \\
\hline credit & 15,886 & 0.0334 & 0.548 & -1.855 & 29.28 \\
debt_cost & 15,877 & 0.0782 & 0.709 & -1.402 & 66.12 \\
size & 15,886 & 22.18 & 1.219 & 16.52 & 27.77 \\
lev & 15,853 & 42.03 & 94.04 & 0.708 & 5808 \\
roe & 15,666 & 7.184 & 26.97 & -1891 & 386.7 \\
bm & 15,418 & 0.616 & 0.246 & 0.00976 & 1.444 \\
return & 15,755 & 0.00368 & 0.0169 & -0.171 & 1.139 \\
volatility & 15,739 & 0.0637 & 0.0510 & $9.26 \times 10-5$ & 5.269 \\
holding & 15,885 & 57.53 & 15.40 & 1.320 & 101.2 \\
abs_rectified_jones & 15,266 & 0.0739 & 0.131 & 0 & 6.548 \\
state_owned & 15,877 & 0.644 & 0.479 & 0 & 1 \\
treated_period & 3671 & 0.163 & 0.370 & & 1 \\
\hline
\end{tabular}

\subsection{Parallel Trend Test}

This paper adopts the DID, and its key assumption is that without the exogenous impact of the introduction of the "Green Credit Guidelines", the loan amount and debt cost of the treatment group and the control group should maintain the same change trend. Therefore, we test whether the changes in the financing amount and corporate debt cost of the treatment group and the control group meet the parallel trend assumption before the "Green Credit Guidelines" are issued. According to this idea, taking the launch of the "Green 
Credit Guidelines" as a node, parallel trend tests are carried out on the changes in the loan amount and debt cost of companies. The results are shown in Figures 2 and 3. As can be seen from the figure, the models of the two dimensions of loan amount and financing cost both meet the parallel trend assumption of the DID.

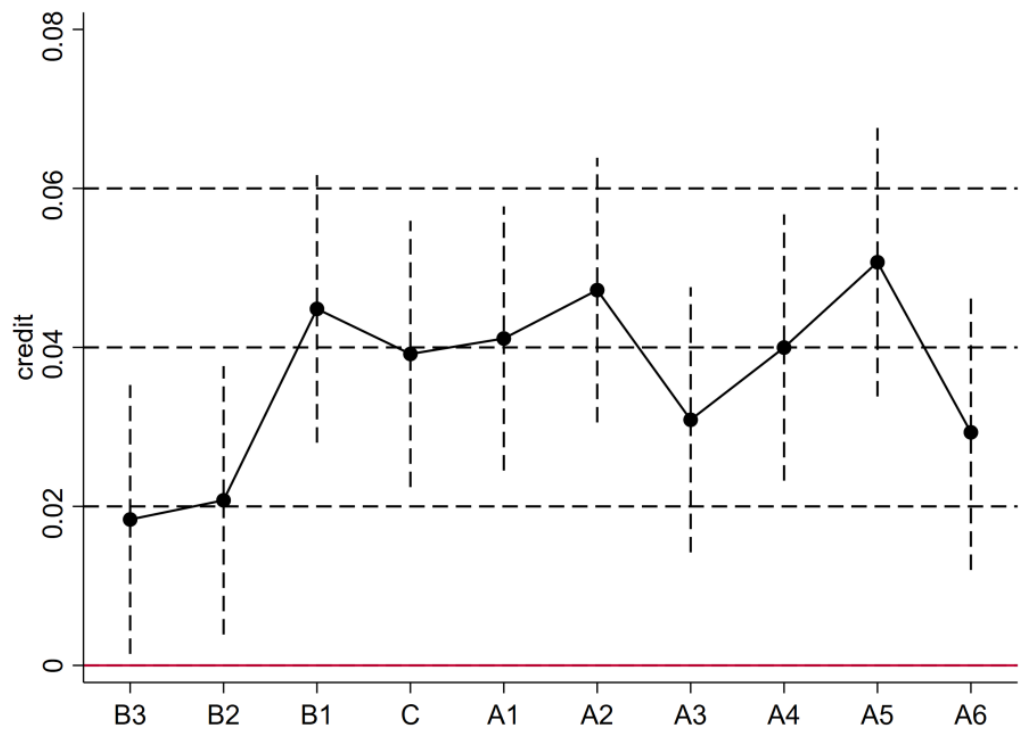

Figure 2. Parallel Trend Test Chart of Company Loan Volume.

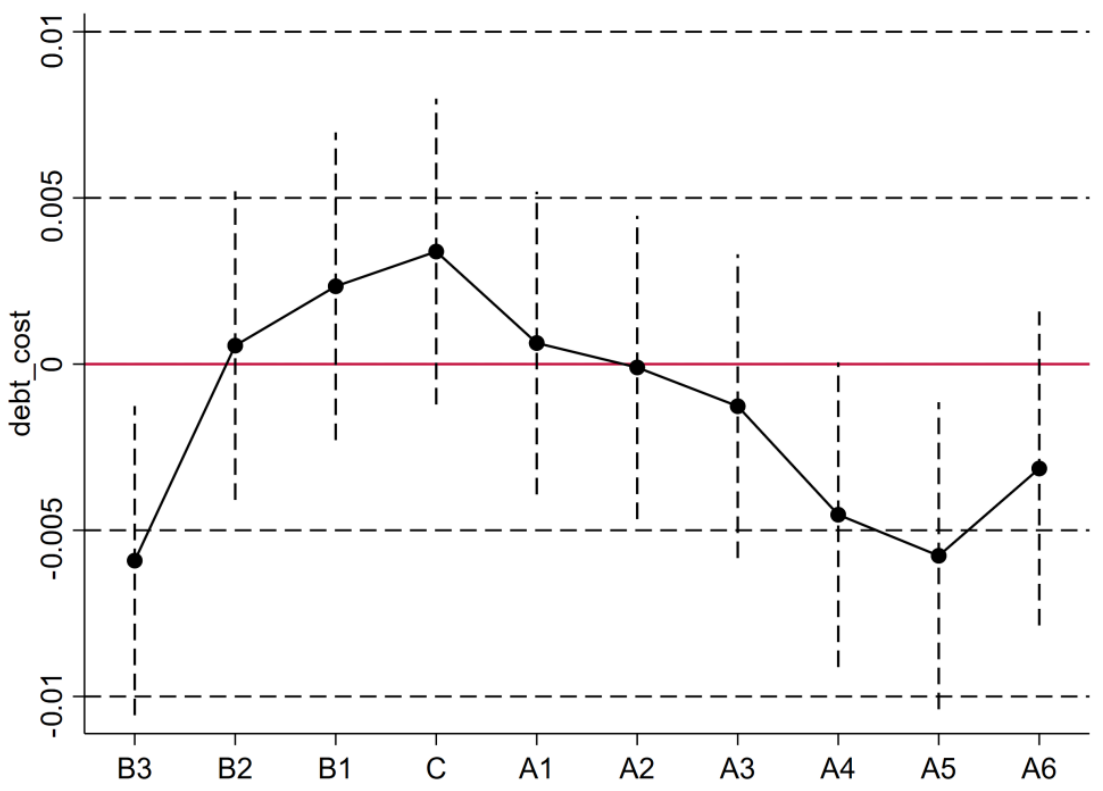

Figure 3. Parallel Trend Test Chart of Company Financing Cost.

\section{Inspection Results and Analysis}

In order to investigate how the introduction of the green credit marked by the "Green Credit Guidelines" affects the acquisition of company loan resources and the impact on the financing cost of companies, and to identify the mechanism, we have conducted the following empirical tests: first, we use the DID to test the impact of the introduction of the policy on the amount of loans obtained by companies; second, test the impact of the introduction of the policy on the financing cost of companies; thirdly, the robustness tests of changing the construction methods of the treatment group and the control group and adjusting the measurement indexes of the sample time window were carried out 
respectively. Fourthly, the heterogeneity of the property right attribute and long-term and short-term loan structure of the company is tested, respectively.

\subsection{Impact of Green Credit Guidelines on Corporate Credit Financing Amount and Financing Cost}

This paper uses a DID model to control the two-way fixed effect to test whether and how the introduction of green credit policies with the release of "Green Credit Guidelines" as a landmark event affects the amount and cost of corporate credit financing. The results of empirical tests are shown in Table 3. The results in the first column of Table 3 show that when controlling individual and annual fixed effects, the coefficient estimation value of Treated_period is positive at the significance level of 5\%. The results in column 2 of Table 3 show that when controlling individual and annual fixed effects, the coefficient estimation of Treated_period is negative at the significance level of $5 \%$. These results show that compared with the control group (polluting companies), the introduction of the green credit marked by the introduction of the "Green Credit Guidelines" has promoted the acquisition of loans and the reduction of debt costs for the treatment group (green companies), and green companies have obtained more and cheaper credit resources.

Table 3. Impact of Policies on Credit Financing Amount and Debt Cost of Green Companies.

\begin{tabular}{|c|c|c|}
\hline Variables & credit_w & debt_cost_w \\
\hline treated_period & $\begin{array}{l}0.00961 * * \\
(0.00390)\end{array}$ & $\begin{array}{c}-0.00209 \text { ** } \\
(0.00106)\end{array}$ \\
\hline size & $\begin{array}{l}0.0165^{* * *} \\
(0.00221)\end{array}$ & $\begin{array}{l}0.00186^{* * *} \\
(0.000604)\end{array}$ \\
\hline lev & $\begin{array}{c}1.85 \times 10^{-5} \\
\left(6.83 \times 10^{-5}\right)\end{array}$ & $\begin{array}{c}-4.40 \times 10^{-5 * *} \\
\left(1.87 \times 10^{-5}\right)\end{array}$ \\
\hline roe & $\begin{array}{l}-2.40 \times 10^{-5} \\
\left(4.70 \times 10^{-5}\right)\end{array}$ & $\begin{array}{c}1.14 \times 10^{-5} \\
\left(1.28 \times 10^{-5}\right)\end{array}$ \\
\hline $\mathrm{bm}$ & $\begin{array}{l}-0.00871 \\
(0.00692)\end{array}$ & $\begin{array}{c}-0.00360 * \\
(0.00189)\end{array}$ \\
\hline return & $\begin{array}{c}-0.0314 \\
(0.125)\end{array}$ & $\begin{array}{c}-0.0696^{* *} \\
(0.0342)\end{array}$ \\
\hline volatility & $\begin{array}{c}-0.0542 \text { * } \\
(0.0319)\end{array}$ & $\begin{array}{c}0.00901 \\
(0.00872) \\
\end{array}$ \\
\hline holding & $\begin{array}{c}-2.75 \times 10^{-5} \\
(0.000107)\end{array}$ & $\begin{array}{l}-2.09 \times 10^{-7} \\
\left(2.92 \times 10^{-5}\right)\end{array}$ \\
\hline abs_rectified_jones & $\begin{array}{l}0.0211^{* * *} \\
(0.00704)\end{array}$ & $\begin{array}{c}-0.00351 * \\
(0.00192)\end{array}$ \\
\hline Constant & $\begin{array}{c}-0.351 * * * \\
(0.0481)\end{array}$ & $\begin{array}{c}0.0169 \\
(0.0131)\end{array}$ \\
\hline Year FE & Controlled & Controlled \\
\hline Firm FE & Controlled & Controlled \\
\hline Observations & 3437 & 3437 \\
\hline R-squared & 0.225 & 0.491 \\
\hline
\end{tabular}

Note: Variance is shown in brackets; ${ }^{* * *},{ }^{* *},{ }^{*}$ are significant at the levels of $1 \%, 5 \%$ and $10 \%$, respectively. The following tables are the same.

\subsection{Robustness Test of Implementation Time of Adjustment Policy}

A placebo-controlled test was conducted in this paper in order to further eliminate the differences in the characteristics of the treatment group and the control group before the "Green Credit Guidelines" were issued and eliminate the interference of variables that are difficult to observe and controlled in the model on the research conclusion. Specifically, 
the release time of the "Green Credit Guidelines" was moved forward by one year to 2011, and 2011 was taken as the implementation point of the simulated policy to test the impact of the release of the simulated "Green Credit Guidelines" on corporate credit financing. Time is used to replace period of the original model in variables, and 0 is assigned before 2011 and 1 is assigned after 2011. We can predict that if the previous conclusion is due to the inherent characteristic difference between the treatment group and the control group or the missing variables that are difficult to observe and control, then even the simulated policy can bring the same results. The results in Table 4 show that it can be found that the interactive item treated $\times$ time is not significant, which further supports that the difference in loan amount and financing cost changes between the treatment group and the control group is brought about by the issuance of "Green Credit Guidelines".

Table 4. Implementation Time of Adjustment Policy.

\begin{tabular}{|c|c|c|}
\hline Variables & credit_w & debt_cost_w \\
\hline treated_time & $\begin{array}{c}0.00852 \\
(0.00543)\end{array}$ & $\begin{array}{l}-0.00150 \\
(0.00148)\end{array}$ \\
\hline size & $\begin{array}{c}0.01713^{* * *} \\
(0.00220)\end{array}$ & $\begin{array}{c}0.00172^{* * *} \\
(0.00060)\end{array}$ \\
\hline lev & $\begin{array}{c}0.00001 \\
(0.00007)\end{array}$ & $\begin{array}{c}-0.00004^{* *} \\
(0.00002)\end{array}$ \\
\hline roe & $\begin{array}{l}-0.00002 \\
(0.00004)\end{array}$ & $\begin{array}{c}0.00001 \\
(0.00001)\end{array}$ \\
\hline bm & $\begin{array}{l}-0.00994 \\
(0.00691)\end{array}$ & $\begin{array}{l}0.00331 * \\
(0.00189)\end{array}$ \\
\hline return & $\begin{array}{l}-0.03397 \\
(0.12535)\end{array}$ & $\begin{array}{l}-0.06881 * \\
(0.03420)\end{array}$ \\
\hline volatility & $\begin{array}{l}-0.05189 \\
(0.03197)\end{array}$ & $\begin{array}{c}0.00857 \\
(0.00872) \\
\end{array}$ \\
\hline holding & $\begin{array}{l}-0.00003 \\
(0.00011)\end{array}$ & $\begin{array}{c}-1.29 \times 10^{-6 * *} \\
(0.00003)\end{array}$ \\
\hline abs_rectified_jones & $\begin{array}{c}0.02115^{* * *} \\
(0.00705)\end{array}$ & $\begin{array}{c}0.00352 \\
(0.00192) \\
\end{array}$ \\
\hline Constant & $\begin{array}{c}-0.34233 \text { *** } \\
(0.04661)\end{array}$ & $\begin{array}{c}0.01393 \\
(0.01272) \\
\end{array}$ \\
\hline Year FE & Controlled & Controlled \\
\hline Firm FE & Controlled & Controlled \\
\hline Observations & 3437 & 3437 \\
\hline R-squared & 0.088 & 0.023 \\
\hline
\end{tabular}

Note: Variance is shown in brackets; ${ }^{* * *}, * *, *$ are significant at the levels of $1 \%, 5 \%$ and $10 \%$, respectively. The following tables are the same.

\subsection{Robustness Test of Adjustment Control Group}

Considering that the "Green Credit Guidelines" may affect the control group, thus causing experimental errors, we changed the construction mode of the treatment group and the control group for relevant tests to ensure the robustness of the results. In addition to green companies and polluting companies, an ordinary company group will be set up, which is all the remaining listed companies after excluding green companies and polluting companies. In the new experiment, green companies will continue to be taken as the treatment group and ordinary companies as the control group. Set the new variable treatedgc as the group variable, with the treatment group assigned 1 and the control group assigned 0 . The treatment process compared with that of green companies and polluting companies. The empirical results are shown in Table 5 . The results in column 1 
of Table 5 show that the coefficient estimation value of treatedgc_period is positive at the significance level of $5 \%$. The results in column 2 of Table 5 show that the coefficient estimate of treatedgc_period is negative at the significance level of $5 \%$. These results show that under the new grouping standard, the promulgation of the "Green Credit Guidelines" still has a significant effect on the credit financing of green companies compared with ordinary companies. The promulgation of the "Green Credit Guidelines" has indeed promoted the reduction of loan acquisition and financing costs for green companies. Green companies have obtained more and cheaper credit resources.

Table 5. Adjustment Control Group for Ordinary Companies.

\begin{tabular}{|c|c|c|}
\hline Variables & credit_w & debt_cost_w \\
\hline treatedgc_period & $\begin{array}{l}0.00663 * * \\
(0.00337)\end{array}$ & $\begin{array}{c}-0.00148^{* *} \\
(0.000077)\end{array}$ \\
\hline size & $\begin{array}{l}0.0117^{* * *} \\
(0.000933)\end{array}$ & $\begin{array}{l}-0.000319 \\
(0.000271)\end{array}$ \\
\hline lev & $\begin{array}{l}-1.21 \times 10^{-5} \\
\left(3.06 \times 10^{-5}\right)\end{array}$ & $\begin{array}{c}-3.57 \times 10^{-5 * * *} \\
\left(8.87 \times 10^{-6}\right)\end{array}$ \\
\hline roe & $\begin{array}{l}-1.30 \times 10^{-5} \\
\left(1.48 \times 10^{-5}\right)\end{array}$ & $\begin{array}{c}8.52 \times 10^{-6 * *} \\
\left(4.29 \times 10^{-6}\right)\end{array}$ \\
\hline $\mathrm{bm}$ & $\begin{array}{l}-0.00251 \\
(0.00312)\end{array}$ & $\begin{array}{l}0.00172 * \\
(0.000904)\end{array}$ \\
\hline return & $\begin{array}{l}0.111 * * \\
(0.0515)\end{array}$ & $\begin{array}{l}-0.0120 \\
(0.0149)\end{array}$ \\
\hline volatility & $\begin{array}{l}-0.0219 \\
(0.0135)\end{array}$ & $\begin{array}{c}0.00388 \\
(0.00391)\end{array}$ \\
\hline holding & $\begin{array}{c}-8.33 \times 10^{-5 *} \\
\left(4.74 \times 10^{-5}\right)\end{array}$ & $\begin{array}{c}-3.33 \times 10^{-5 * *} \\
\left(1.38 \times 10^{-5}\right)\end{array}$ \\
\hline abs_rectified_jones & $\begin{array}{l}0.0197 * * * \\
(0.00299)\end{array}$ & $\begin{array}{c}0.000192 \\
(0.000867)\end{array}$ \\
\hline Constant & $\begin{array}{c}-0.241^{* * *} \\
(0.0198)\end{array}$ & $\begin{array}{l}0.0633^{* * *} \\
(0.00575)\end{array}$ \\
\hline Observations & 14,707 & 14,707 \\
\hline R-squared & 0.218 & 0.458 \\
\hline
\end{tabular}

Note: Variance is shown in brackets; ${ }^{* * *},{ }^{* *},{ }^{*}$ are significant at the levels of $1 \%, 5 \%$ and $10 \%$, respectively. The following tables are the same.

\subsection{The Impact of Green Credit Guidelines on Financing Amount and Financing Cost of Companies: Expansion Test}

In order to further explore the mechanism of the introduction of "Green Credit Guidelines" on corporate credit resources and financing costs, we use DDD to test whether the impact of "Green Credit Guidelines" on corporate credit resources acquisition and financing costs shows differences from the perspective of corporate ownership nature and regional differences.

\subsubsection{Based on the Nature of the Property Right of the Company}

Under the specific institutional background of China, the ultimate actual controller of state-owned companies is theoretically the government. In order to ensure employment and social stability, the government will generally give preferential policies and crisis assistance to state-owned companies, which virtually endorses and increases the hidden credit of state-owned companies. In practice, financial institutions generally believe that state-owned companies seldom close down, and the government will rescue them even if they encounter operational difficulties. Therefore, the conditions for banks to lend to 
state-owned companies will be much looser than those for private companies. Therefore, the same policy may have different effects on companies with different property rights. Therefore, we further divide the sample into two groups according to the nature of company property rights, state-owned companies, and non-state-owned companies. The variable soe represents the nature of company property rights, state-owned companies are assigned 1 as the treatment group, and non-state-owned companies are assigned 0 as the control group, and then DDD test is carried out. The test results are shown in Table 6 . The results in the first column of Table 6 show that on the basis that the coefficient of double interaction item treated_period_soe is still significantly positive, the coefficient estimation value of DDD item treated_period_soe is significantly negative at the level of 1\%, which indicates that the "Green Credit Guidelines" inhibit the loan acquisition advantages of state-owned companies over non-state-owned companies. Compared with non-state-owned companies, the promotion effect of "Green Credit Guidelines" on the amount of loans is relatively weak for state-owned companies. The results in the second column show that on the basis of the double interaction item Treated_period coefficient still being significantly negative, the coefficient estimation value of the DDD item Treated_period is significantly positive at the level of $1 \%$, which indicates that the "Green Credit Guidelines" inhibit the financing cost advantage of state-owned companies compared with non-state-owned companies. Compared with non-state-owned companies, the "Green Credit Guidelines" have a relatively weak effect on reducing financing costs for state-owned companies. Therefore, the green credit has reduced the advantages of state-owned companies in obtaining financial resources from non-state-owned companies, and to a certain extent has slowed down the inequality of competition between state-owned companies and non-state-owned companies. These results verify hypothesis 3 proposed in this paper.

Table 6. Heterogeneity Test of Companies with Different Property Rights.

\begin{tabular}{|c|c|c|}
\hline Variables & credit_w & debt_cost_w \\
\hline treated_period_soe & $\begin{array}{c}-0.00456^{* * *} \\
(0.00142)\end{array}$ & $\begin{array}{c}0.22022 \text { *** } \\
(0.02194)\end{array}$ \\
\hline period_soe & $\begin{array}{c}-0.00269^{* * *} \\
(0.00055)\end{array}$ & $\begin{array}{c}-0.15054^{* * *} \\
(0.01224)\end{array}$ \\
\hline treated_period & $\begin{array}{c}0.01269 * * * \\
(0.00185)\end{array}$ & $\begin{array}{c}-0.13096^{* * *} \\
(0.02608)\end{array}$ \\
\hline treated_soe & $\begin{array}{c}0.03265^{* * *} \\
(0.00577)\end{array}$ & $\begin{array}{c}-0.31836^{* * *} \\
(0.06297)\end{array}$ \\
\hline size & $\begin{array}{c}0.01661 \text { *** } \\
(0.00391)\end{array}$ & $\begin{array}{c}0.02556 \\
(0.02066)\end{array}$ \\
\hline lev & $\begin{array}{c}0.00001 \\
(0.00005)\end{array}$ & $\begin{array}{c}-0.00097^{* * * *} \\
(0.00034)\end{array}$ \\
\hline roe & $\begin{array}{l}-0.00003 \\
(0.00002)\end{array}$ & $\begin{array}{l}-0.00021 \\
(0.00073)\end{array}$ \\
\hline $\mathrm{bm}$ & $\begin{array}{c}-0.00869^{* * *} \\
(0.00177)\end{array}$ & $\begin{array}{l}-0.00900 \\
(0.03030)\end{array}$ \\
\hline return & $\begin{array}{l}-0.03079 \\
(0.11406)\end{array}$ & $\begin{array}{l}-1.89215 \\
(4.0693)\end{array}$ \\
\hline volatility & $\begin{array}{c}-0.05301^{* * *} \\
(0.01693)\end{array}$ & $\begin{array}{c}0.64737 \\
(0.43180)\end{array}$ \\
\hline holding & $\begin{array}{l}-0.00003 \\
(0.00009)\end{array}$ & $\begin{array}{l}-0.00135 \\
(0.00361)\end{array}$ \\
\hline abs_rectified_jones & $\begin{array}{c}0.02089 * * * \\
(0.00547)\end{array}$ & $\begin{array}{c}0.01121 \\
(0.02186)\end{array}$ \\
\hline
\end{tabular}


Table 6. Cont.

\begin{tabular}{ccc}
\hline Variables & credit_w & debt_cost_w \\
\hline Constant & $-0.35151^{* * *}$ & 0.16613 \\
& $(0.08379)$ & $(0.23713)$ \\
\hline Year FE & Controlled & Controlled \\
\hline Firm FE & Controlled & Controlled \\
\hline Observations & 3437 & 3437 \\
\hline R-squared & 0.225 & 0.117 \\
\hline
\end{tabular}

Note: Variance is shown in brackets; ${ }^{* * *}$ is significant at the levels of $1 \%$. The following tables are the same.

\subsubsection{Based on the Location of the Company}

Due to the obvious differences in the level of regional economic development in China and the great differences in the industrial structure in different regions, the same policy may have different effects on different regions. According to the level of economic development in the region where the company is located and the classification standard of domestic regions by the National Development and Reform Commission of China, we further subdivide the company samples into the eastern group and the central and western group according to the region where the company is located. The variable province represents the region where the company is located, the eastern group is assigned 1 as the treatment group, and the western group is assigned 0 as the control group, and then further tests are carried out. The test results are shown in Table 7. The results in the first column of Table 7 show that on the basis that the coefficient of double interaction item Treated_period is still significantly positive, the coefficient estimation value of DDD item treated_period_provision is significantly negative at the level of $1 \%$, which indicates that the promotion effect of "Green Credit Guidelines" on loan quantity is relatively weak in areas with better economic development level compared with areas with lower economic development level. The results in the second column show that on the basis that the coefficient of double interaction item treated period is still significantly negative, the coefficient estimation value of DDD item treated_period_provision is significantly positive at the level of $1 \%$, which indicates that the effect of "Green Credit Guidelines" on reducing financing costs is relatively weak in regions with better economic development level compared with regions with lower economic development level. These results verify hypothesis 4 proposed in this paper.

Table 7. Heterogeneity Test of Companies in Different Regions.

\begin{tabular}{|c|c|c|}
\hline Variables & credit_w & debt_cost_w \\
\hline treated_period_province & $\begin{array}{c}-0.00832^{* * *} \\
(0.00112)\end{array}$ & $\begin{array}{c}0.18047^{* * *} \\
(0.00860)\end{array}$ \\
\hline period_province & $\begin{array}{c}0.01551 * * * \\
(0.00091)\end{array}$ & $\begin{array}{c}-0.10782 * * * \\
(0.00524)\end{array}$ \\
\hline treated_period & $\begin{array}{c}0.01382^{* * *} \\
(0.00030)\end{array}$ & $\begin{array}{c}-0.09338 * * * \\
(0.00063)\end{array}$ \\
\hline treated_province & $\begin{array}{c}0.02197 * * * \\
(0.00076)\end{array}$ & $\begin{array}{c}-0.34847^{* * * *} \\
(0.06945)\end{array}$ \\
\hline size & $\begin{array}{c}0.01589 * * * \\
(0.00268)\end{array}$ & $\begin{array}{c}0.02505^{* * *} \\
(0.00348)\end{array}$ \\
\hline
\end{tabular}


Table 7. Cont.

\begin{tabular}{|c|c|c|}
\hline Variables & credit_w & debt_cost_w \\
\hline lev & $\begin{array}{c}0.00003 \\
(0.00002)\end{array}$ & $\begin{array}{c}-0.00099^{* * *} \\
(0.00020)\end{array}$ \\
\hline roe & $\begin{array}{c}-0.00002 * \\
(0.00001)\end{array}$ & $\begin{array}{l}-0.00009 \\
(0.00029)\end{array}$ \\
\hline $\mathrm{bm}$ & $\begin{array}{l}-0.00542 \\
(0.00116)\end{array}$ & $\begin{array}{l}-0.02429 \\
(0.08084)\end{array}$ \\
\hline return & $\begin{array}{l}-0.04228 \\
(0.13022)\end{array}$ & $\begin{array}{l}-1.80243 \\
(3.43154)\end{array}$ \\
\hline volatility & $\begin{array}{c}-0.05402 * * * \\
(0.00848)\end{array}$ & $\begin{array}{l}0.62886 * \\
(0.31870)\end{array}$ \\
\hline holding & $\begin{array}{c}2.47 \times 10^{-6} \\
(0.00009)\end{array}$ & $\begin{array}{c}-0.00117 \\
(0.00378)\end{array}$ \\
\hline abs_rectified_jones & $\begin{array}{c}0.02110 \\
(0.01016)\end{array}$ & $\begin{array}{c}0.01965 \\
(0.01805)\end{array}$ \\
\hline Constant & $\begin{array}{c}-0.33405^{* * *} \\
(0.07261)\end{array}$ & $\begin{array}{l}0.13273 * * \\
(0.10182)\end{array}$ \\
\hline Year FE & Controlled & \\
\hline Firm FE & Controlled & \\
\hline Observations & 3437 & 3437 \\
\hline R-squared & 0.229 & 0.117 \\
\hline
\end{tabular}

Note: Variance is shown in brackets; ${ }^{* * *},{ }^{* *},{ }^{*}$ are significant at the levels of $1 \%, 5 \%$ and $10 \%$, respectively. The following tables are the same.

\section{Conclusions and Policy Recommendations}

\subsection{Conclusions}

Firstly, this paper constructs the evaluation standard of the effect of green credit policy based on the two indicators of credit amount and financing interest rate, which serves as the research foothold of environmental regulation policy on the availability of enterprise financing. Then, a quasi-natural experiment is constructed based on the publication of the "Green Credit Guidelines". The DID is used to test the effect of the implementation of the "Green Credit Guidelines" on the loan amount and financing interest rate of green enterprises and polluting enterprises. Chinese scholars have found in their studies that the implementation of green credit policies can guide social capital to flow to low-carbon, environment-friendly and green industries, while inhibiting the reinvestment and expansion of pollution-intensive industrial enterprises (Guo et al., 2018) [21]. The empirical test results of this paper show that the green credit policy makes green enterprises obtain more credit resources than polluting enterprises, and makes green enterprises obtain cheaper financing costs than polluting enterprises. This result can well explain the reasons for the changes in the management behaviors of green enterprises and polluting enterprises pointed out by Guo et al. Their research also provides confirmation for the research results of this paper. The introduction of "Green Credit Guidelines" has indeed significantly changed the financing availability of green enterprises, adjusted the allocation direction of credit resources and realized the optimal allocation of credit resources.

When studying the different effects of green financial policies on different types of polluting enterprises, some scholars found that in China, compared with heavily polluting non-state-owned enterprises, heavily polluting state-owned enterprises are more strongly inhibited in credit financing (Ding, 2019) [37]. Considering the high proportion of China's state-owned enterprises in the economy and the great differences in the level of economic development in different regions. In this paper, from the two perspectives of the nature of enterprise property rights and the region where the enterprise is located, the DDD is used 
to further study the effectiveness of policy effects. The study found that the green credit policy has a stronger effect on non-state-owned enterprises in promoting access to credit resources. In terms of reducing the financing cost of enterprises, it has a better effect on relatively backward regions. The introduction of the "Green Credit Guidelines" has to a certain extent reduced the original credit resource advantages of state-owned enterprises over non-state-owned enterprises and enterprises in relatively developed regions over enterprises in relatively backward regions.

\subsection{Policy Recommendations}

Through the empirical study of the "Green Credit Guidelines", we find that the green credit policy can well guide and adjust the investment of financial resources, promote the effective utilization of resources and help the sustainable development of the economy. However, in combing China's green credit policy and studying the shortcomings of the "Green Credit Guidelines", we have also found some problems, such as the lack of unity in China's domestic green credit policies, the inconsistency with international standards, the lack of scientific environmental impact and risk assessment of credit projects, and the lack of clear incentive and restraint mechanisms for all relevant subjects. Therefore, this paper believes that the following aspects can be improved and provide reference for other countries to formulate green credit policies.

First, unify the domestic "green" accreditation standards and conform to the international accreditation standards. The documents issued by various regulatory authorities in China have different standards for the identification of green credit, which leads to numerous and jumbled standards for banks to implement green credit and frequent fake green credit projects. We believe that regulatory agencies can consider unified identification of "green" standards in the subsequent formulation of green credit policies, and learn from international experience to realize mutual recognition with international standards.

Second, formulate a clear incentive and restraint mechanism for green credit policies, and use market-oriented means to encourage and restrict commercial entities as much as possible. Link the responsibilities and incentives of financial institutions and enterprises with environmental pollution indicators. We should step up punishment for enterprises that do not meet the environmental protection standards and internalize the negative externalities of pollution as much as possible; support for green enterprises is linked to the level of environmental protection projects, and additional rewards should be given to enterprises and financial institutions with outstanding green development performance and outstanding achievements.

Third, the policies for different types of enterprises are different. Under the condition of unequal competition, the weak side is given a certain policy preference. In terms of policies, relatively weak green enterprises such as small and medium-sized enterprises and non-state-owned enterprises should be supported to enter the credit market, and policy guarantee agencies should be set up to guarantee and increase credit for them to obtain credit; Encourage commercial banks to issue green loans to relatively weak enterprises and give certain special tax concessions.

Fourth, establish and perfect a trading market that internalizes environmental utility. Encourage the development of multi-level emission rights and emission rights trading markets, explore trading markets based on "carbon emission rights and emission rights", transform positive externalities of environmental protection into the income and competitive advantages of enterprises and, at the same time, let enterprises that produce negative externalities of environment bear the responsibility costs they should bear: internalization of environmental benefits through market mechanism.

Author Contributions: G.Z., C.L. and S.L. contributed equally to this work. All authors have read and agreed to the published version of the manuscript.

Funding: The research for this paper was supported by the National Natural Science Foundation of China (No. 71573170 and No. 71573050). 
Institutional Review Board Statement: Not applicable.

Informed Consent Statement: Not applicable.

Data Availability Statement: Publicly available datasets were analyzed in this study. This data can be found here: [https:// pan.baidu.com/s/1fQI719TNwF85-oksAqKEXA/2021].

Acknowledgments: We thank the anonymous reviewers for their valuable comments that have important significances to our research.

Conflicts of Interest: The authors declare no conflict of interest.

\section{References}

1. Ma, J.; Shi, Y. Green Finance Policy and Its Applications in China. J. Financ. Rev. 2014, 2, 79-107. (In Chinese)

2. Ma, J. Using Financial Instruments to Ease the Financing Difficulties of Green Enterprises. J. Financ. Rev. 2015, 10, 9-11. (In Chinese)

3. Altenburg, T.; Rodrik, D. Green industrial policy: Accelerating structural change towards wealthy green economies. J. Rev. Econ. Policy 2017, 3, 469-491.

4. Brammer, S.; Brooks, C.; Pavelin, S. Corporate Social Performance and Stock Returns: UK Evidence From Disaggregate Measures. J. Financ. Manag. 2006, 3, 97-116. [CrossRef]

5. Van Dijken, F. Corporate Social Responsibility: Market Regulation and the Evidence. Manag. Law 2007, 4, 141-184. [CrossRef]

6. Uadiale, O.M.; Fagbemi, T.O. Corporate social responsibility and financial performance in developing economies: The Nigerian experience. J. Econ. Sustain. 2012, 4, 44-54.

7. Li, D.; Zhao, Y.; Sun, Y. Corporate environmental performance, environmental information disclosure, and financial performance: Evidence from China. J. Hum. Ecol. Risk Assess. 2017, 2, 323-339. [CrossRef]

8. He, L.; Liu, R.; Zhong, Z.; Wang, D.; Xia, Y. Can Green Financial Development Promote Renewable Energy Investment Efficiency? A Consideration of Bank Credit. J. Renew. Energ. 2019, 143, 974-984. [CrossRef]

9. Wang, K.S.; Su, X.R.; Wang, F.R. Development of Green Finance, Debt Maturity Structure and Investment of Green Enterprise. J. Financ. 2019, 7, 9-19.

10. Volz, U. Fostering Green Finance for Sustainable Development in Asia; Asian Development Bank Institute Working Paper; Asian Development Bank Institute: Tokyo, Japan, 2018; p. 814.

11. Labatt, S.; White, R.R. Environmental Finance: A Guide to Environmental Risk Assessment and Financial Products. J. Transplant. 2002, 8, 405-409.

12. Aizawa, M.; Yang, C. Green Credit, Green Stimulus, Green Revolution? China's Mobilization of Banks for Environmental Cleanup. J. Environ. Dev. 2010, 2, 119-144. [CrossRef]

13. China Banking Association. Social Responsibility Report of China's Banking Sector; China Financial Publishing House: Beijing, China, 2019. (In Chinese)

14. Hu, W.G. Research on the Relationships between the Property Right and the Exploitation Externality of the Coal Resoyrce and the Reform of the Property Right; Tsinghua University: Beijing, China, 2009. (In Chinese)

15. Kang, Y.J.; Jung, S.Y.; Lee, H. The Impact of Green Credit Policy on Manufacturers' Efforts to Reduce Suppliers' Pollution. J. Clean. Prod. 2019, 248, 119271. [CrossRef]

16. Kulpa, W. Environmental risk management in loan activity in Polish banks. J. Bus. Retail Manag. Res. $2016,10,44-52$.

17. Wang, E.; Liu, X.; Wu, J.; Cai, D. Green Credit, Debt Maturity, and Corporate Investment-Evidence from China. J. Sustain. 2019, 11, 583. [CrossRef]

18. Guo, Q.; Zhou, M.; Liu, N.; Wang, Y. Spatial Effects of Environmental Regulation and Green Credits on Green Technology Innovation under Low-Carbon Economy Background Conditions. J. Environ. Res. Public Health. 2019, 16, 3027. [CrossRef]

19. Chen, H.; Liu, C.; Xie, F.; Zhang, T.; Guan, F. Green Credit and Company R\&D Level: Empirical Research Based on Threshold Effects. J. Sustain. 2019, 11,1-14.

20. Su, D.W.; Lian, L.L. Does Green Credit Policy Affect Corporate Financing and Investment? Evidence from Publicly Listed Firms in Pollution-Intensive Industries. J. Financ. Res. 2018, 12, 123-137. (In Chinese)

21. Guo, Y.Y.; Xia, X.N.; Zhang, S.; Zhang, D.P. Environmental Regulation, Government R\&D Funding and Green Technology Innovation: Evidence from China Provincial Data. J. Sustain. 2018, 10, 940.

22. Hu, Y.Q.; Jiang, H.; Zhong, Z. Impact of green credit on industrial structure in China: Theoretical mechanism and empirical analysis. J. Sci. Pollut. Res. 2020, 27, 10506-10519. [CrossRef]

23. Scholtens, B.; Dam, L. Banking on the Equator. Are Banks that Adopted the Equator Principles Different from Non-Adopters? J. World Dev. 2007, 35, 1307-1328. [CrossRef]

24. Salazar, J. Environmental Finance: Linking Two World. Presented at a Workshop on Finance Innovations for Biodiversity Bratislava. 1998, 1, 2-18.

25. Cai, H.J.; Wang, X.; Tan, C. Green Credit Policy, Incremental Bank Loans and Environmental Protection Effect. J. Account. Res. 2019, 3, 88-95. (In Chinese) 
26. Cilliers, E.J.; Diemont, E.; Stobbelaar, D.J.; Timmermans, W. Sustainable Green Urban Planning: The Green Credit Tool. J. Place. Manag. Dev. 2010, 1, 57-66. [CrossRef]

27. Street, P.; Monaghan, P.E. Assessing the sustainability of bank service channels: The case of The Co-operative Bank. J. Sustain. Bank Green. Financ. 2013, 16, 72-87.

28. Chen, N.W.; Huang, H.H.; Lin, C.H. Equator Principles and Bank Liquidity. J. Int. Rev. Econ. Financ. 2018, 55, 185-202. [CrossRef]

29. Faulkender, M.; Petersen, M.A. Does the source of capital affect capital structure? J. Rev. Financ. Stud. 2003, 1, 45-79.

30. Lemmon, M.; Roberts, M.R. The Response of Corporate Financing and Investment to Changes in the Supply of Credit. J. Financ. Quant. Anal. 2010, 3, 555-587. [CrossRef]

31. He, L.Y.; Zhang, L.; Zhong, Z.; Wang, D.; Wang, F. Green credit, renewable energy investment and green economy development: Empirical analysis based on 150 listed companies of China. J. Clean. Prod. 2018, 208, 363-372. [CrossRef]

32. Xu, X.K.; Li, J.S. Asymmetric Impacts of the Policy and Development of Green Credit on the Debt Financing Cost and Maturity of Different Types of Enterprises in China. J. Clean. Prod. 2020, 264, 121574. [CrossRef]

33. Brandt, L.; Li, H. Bank discrimination in transition economies: Ideology, information, or incentives? J. Comp. Econ. 2002, 31, 387-413. [CrossRef]

34. Athey, S.; Imbens, G.W. Identification and Inference in Nonlinear Difference-in-Differences Models. J. Comp. Econ. 2006, 74, 431-497. [CrossRef]

35. Meyer, B.D. Natural and Quasi-Natural Experiments in Economics. J. Bus. Econ. Stat. 1995, 13, $151-161$.

36. Qian, X.S.; Tang, Y.L.; Sheng, F. Does Reform of the Security Interests System Reduce the Cost of Corporate Debt? Evidence from a Natural Experiment in China. J. Financ. Resear. 2019, 7, 115-134. (In Chinese)

37. Ding, J. Green Credit Policy, Credit Resources Allocation and Strategic Response of Enterprises. J. Econ. Rev. 2019, 4, 62-76. (In Chinese) 